\title{
Degummed Pongamia oil - Ethanol microemulsions as novel alternative CI engine fuels for remote Small Island Developing States: Preparation, characterization, engine performance and emissions characteristics
}

\author{
Salvin S. Prasad ${ }^{\text {a, b, * }}$, Anirudh Singh ${ }^{\text {a, c }}$, Surendra Prasad ${ }^{a}$ \\ ${ }^{a}$ Faculty of Science, Technology and Environment, The University of the South Pacific, Laucala Campus, Suva, Fiji \\ ${ }^{\mathrm{b}}$ College of Engineering, Science and Technology, Fiji National University, P. O. Box 7222, Nasinu, Fiji \\ ' School of Science and Technology, The University of Fiji, Private Mail Bag, Lautoka, Fiji
}

\section{A R T I C L E I N F O}

\section{Article history:}

Received 3 April 2019

Received in revised form

15 December 2019

Accepted 31 December 2019

Available online 31 December 2019

\section{Keywords:}

Pongamia oil

Ethanol

Hybrid fuels

Fuel characteristics

Efficiency

Emissions

\begin{abstract}
A B S T R A C T
Diminishing fossil fuel reserves, rising market price for diesel and the need to combat greenhouse gas emissions have led to the development of a crucial area of research into alternative fuels for diesel engines. In this work, a hybrid fuel was prepared for the first time by blending Pongamia oil, hydrated ethanol (95\% purity) and butanol (as a surfactant). To eliminate engine modification and reduce injector clogging in the diesel engine, degummed Pongamia oil was utilized for preparing hybrid fuels. The results show that the density and viscosity of Pongamia oil reduced considerably after blending with ethanol and was brought closer to that of diesel. The gross calorific values were comparable with that of diesel. The brake thermal efficiencies of using hybrid fuels on a compression ignition engine were very similar to that of diesel. The emissions characteristics of hybrid fuels show reduced emissions of $\mathrm{CO}_{2}, \mathrm{NO}_{\mathrm{x}}$ and $\mathrm{SO}_{2}$. The hybrid fuel blends $\mathrm{E}_{22} \mathrm{~B}_{27} \mathrm{DPO}_{51}$ and $\mathrm{E}_{17} \mathrm{~B}_{16} \mathrm{DPO}_{67}$ prepared with degummed Pongamia oil show the lowest emissions. Thus, these hybrid fuels have the potential to substitute diesel to run diesel powered inter-island shipping vessels, fishing boats and smaller power plants for household electricity in remote and outer islands of developing countries.
\end{abstract}

(c) 2020 Elsevier Ltd. All rights reserved.

\section{Introduction}

While there is a global movement towards the use of more environmentally-friendly alternatives, fossil fuels such as crude oil and its derivatives, natural gas, and coal still furnish most of the world's energy needs for electricity generation, transportation and industrial requirements. Burning of such fuels under complete and incomplete combustion releases Green House Gases (GHGs) that include Carbon Dioxide $\left(\mathrm{CO}_{2}\right)$, Carbon Monoxide (CO), Hydrocarbons $(\mathrm{HC})$, Sulphur Dioxide $\left(\mathrm{SO}_{2}\right)$, Nitrous Oxide $\left(\mathrm{N}_{2} \mathrm{O}\right)$ and other Nitrogen Oxides $\left(\mathrm{NO}_{\mathrm{x}}\right)$, which are key contributors to climate change [1,2]. Such environmental concerns to mitigate climate change have led to the development of various techniques for reducing GHG emissions from diesel engines, however, no

\footnotetext{
* Corresponding author. Faculty of Science, Technology and Environment, The University of the South Pacific, Laucala Campus, Suva, Fiji.

E-mail address: psdshalvin@gmail.com (S.S. Prasad).
}

significant reductions in fossil fuel combustion have been achieved overall [3]. The problem has been exacerbated by an escalating demand for such non-renewable sources of energy and diminishing underground fossil fuel reserves, which present questions of fuel sustainability and a potential fuel crisis in the near future [4]. The consequences have led to a rise in global fuel price over the years, with serious adverse impacts on developing countries, which rely on imported fossil fuels for their development [5].

The absence of indigenous fossil fuel reserves in most Small Island Developing States (SIDS), including the Pacific Island Countries (PICs), leaves them with no option but to import diesel and other fuels at high costs [6]. Such high import bills and the commitments of these countries to global GHG emission reduction agreements have driven them towards seeking more sustainable sources of fuel.

As alternatives to diesel fuel, vegetable oils have been tested for their fuel characteristics, performance and emissions on diesel engines. In the case of SIDS such as Fiji, these fuels provide the 
opportunity for reducing global carbon emissions as well as reducing the national fuel import bills. However, the inherent high viscosity of such vegetable oils produces poor atomization and incomplete combustion leading to higher smoke density $[7,8]$. The high viscosity of vegetable oil may be reduced by blending with diesel fuel or by increasing the temperature. While, such techniques may mitigate the problems to some degree, they do not eliminate them entirely $[9,10]$. Carbon buildup (coking) and injector clogging continues over time, resulting in high maintenance costs and/or shorter life of Compression Ignition (CI) engines. Success has been reported for blends of vegetable oil and diesel in diesel engine with vegetable oil percentage composition up to $20 \%$, however, the high viscosity and low volatility of the vegetable oil becomes a major drawback for their utilization at higher percentage composition in the blends [11].

As discussed by Ref. [12], injector clogging of CI engines is reduced when degummed vegetable oil is blended with diesel, as the degumming process removes phospholipids from the fuel blend. Viscosity and exhaust emissions of vegetable oil blends in diesel engines can be further reduced by converting such vegetable oils into biofuels through the processes of transesterification into biodiesel, pyrolysis and microemulsification into hybrid fuel [13]. Biofuels produced through pyrolysis show lower viscosity but have unacceptable ash, carbon residue and pour point [14]. Transesterification of vegetable oil and alcohol into esters (biodiesel) have shown reduced viscosity with minimized greenhouse gas emissions [15]. However, the purification stages and by-product formation requires high energy input with long reaction time, which makes the entire process very expensive $[16,17]$. The preparation of, vegetable oil-based microemulsification reduces the oil viscosity using low viscosity alcohols while eliminating the chemical reactions and avoiding the unpurified glycerol [18]. Furthermore, the low carbon emission advantage of such fuels over fossil fuels is maintained if the alcohol used is a biofuel such as bioethanol.

This study investigates the performance of $\mathrm{CI}$ engines using hybrid fuels produced by microemulsification of Degummed Pongamia Oil (DPO) with alcohol and a suitable surfactant. Pongamia oil blends with diesel and Pongamia biodiesel are already experimented for their fuel characteristics, performance on diesel engine and greenhouse gas emissions [19,20]. However, the microemulsions of DPO and hydrated ethanol (so called hybrid fuels) have not been investigated for diesel engine before. Pongamia oil and ethanol are the major feedstock for hybrid fuel production and the SIDS, including the PICs, have high potential for the indigenous production of such feedstock to substitute for diesel in diesel engines and cater for most of their energy needs.

Pongamia is a forest based tree that has the ability to survive on many types of soils (including saline soils), has low moisture demand, requires minimum input and the tree yields fruits after 4-7 years [21]. The oil content of Pongamia seed kernel is 30\%-40\% (w/ $\mathrm{w}$ ) and the tree has a productive lifespan of at least 65 years $[22,23]$. Pongamia oil use avoids the food versus fuel controversy, as in the case of coconut oil in PICs because the former is an inedible oil, which contains some toxic components and is unsuitable for food industry [24].

Methanol and ethanol are two common alcohols utilized in microemulsifications of vegetable oil $[18,25]$. Blends of ethanol with vegetable oil contain higher Oxygen $\left(\mathrm{O}_{2}\right)$ concentrations, which provide the potential for complete combustion and considerable reductions in $\mathrm{NO}_{\mathrm{x}}$ and particulate emissions [26]. The use of hydrous ethanol with low water content reduces the combustion and exhaust temperature, which leads to reduction in $\mathrm{NO}_{\mathrm{x}}$ emission [27]. However, while preparing hybrid fuel blends with higher percentage composition of ethanol, a surfactant is needed for its solubility into vegetable oil to effect microemulsification. Octanol and butanol are two commonly utilized surfactants [28]. Butanol is a non-ionic surfactant, which is compatible with other types of surfactants and converts the mixture of vegetable oil and aqueous alcohol to a microemulsion without the need for an ionic emulsifier [29].

Furthermore, [30] have formulated blends of microemulsion biofuel with palm oil and ethanol, using methyl oleate as surfactant and tested them on diesel engine. The emissions analysis showed reduced NOx and exhaust gas temperature. However, there was no significant difference in the carbon monoxide (CO) emissions when compared to those of diesel. [31] tested blends of coconut oil and $20 \%$ butyl alcohol microemulsions on diesel engine and showed that at fixed injection pressure, fixed ambient temperature and at higher ambient air pressure (25 bar) inside the combustion chamber, the ignition delay of diesel and microemulsion of coconut oil are comparable with matching combustion characteristics.

This paper reports the work carried out to develop hybrid fuel blends using Pongamia oil (both crude and degummed) and hydrated ethanol for diesel engine through microemulsification. It reports the relevant fuel properties of such blends, their performance on diesel engine and respective emissions characteristics. In addition, the paper discusses a full Life Cycle Impact Assessment (LCIA) of the carbon emission of the microemulsions in comparison with the petroleum diesel fuel that they will replace in $\mathrm{CI}$ engines. The most suitable blend of hybrid fuel obtained in this study can be utilized as a substitute for diesel fuel to run diesel powered fishing boats, inter-island shipping vessels and smaller diesel power plants for household electricity without any engine modifications in remote and outer islands of developing countries, such as the PICs.

\section{Materials and methods}

The major constituents for hybrid fuels were Pongamia oil, ethanol and butanol. Crude Pongamia Oil (CPO) was purchased from SVM Exports, Tamilnadu, India. Ethanol and butanol were purchased from Altimed Australia Pty Ltd, North Sydney, Australia.

CPO was degummed by removing the phospholipids as in [32]. Water ( $5 \%$ by volume) was added to $\mathrm{CPO}$ and heated to $80^{\circ} \mathrm{C}$ with consistent stirring. The mixture was centrifuged for $20 \mathrm{~min}$ at $4600 \mathrm{rpm}$ and after the gums settled, the oil phase was poured into a clean beaker. Phosphoric acid (14\%) was added in the amount of $0.1 \%$ by weight of oil and mixed intensively for nearly $5 \mathrm{~min}$. $\mathrm{NaOH}$ ( $20 \%$ water solution) was added in the amount of $0.3 \%$ by weight of oil to partially neutralize the phosphoric acid and then heated using a magnetic stirrer for $10 \mathrm{~min}$. The hydrated phosphatides were then removed through 20 min of centrifugation and finally DPO was separated from the gums.

To study the phase behavior and miscibility of the microemulsion using principles of ternary phase diagram, blends of hybrid fuel were prepared using hydrated ethanol of 95\% purity with Pongamia oil by titration at $29^{\circ} \mathrm{C}$. Different blends were prepared by titrating ethanol from $1 \%$ to $19 \%$ (by volume), at $2 \%$ increments, into Pongamia oil to identify the miscibility point. Other blends were prepared by titrating ethanol from $10 \%$ (by volume) at $10 \%$ increment into Pongamia oil. The mixture of different blends initially became cloudy and phase separated after a few minutes. All the blends having ethanol up to $9 \%$ form homogeneous mixture. Other blends form cloudy solution and phase separate within few minutes. Butanol was added as a surfactant to these blends using a burette and thoroughly stirred. When the mixture became clear, the blends were kept under observation for 1 week to confirm their miscibility. The process of adding butanol and mixing continued with blends that phase separate, until a homogenous mixture of hybrid fuel was obtained. These blends 
were kept in vials to further observe the solubility and stability.

To study the fuel characteristics, performance on $\mathrm{CI}$ engine and its exhaust emissions, 6 blends of stable hybrid fuels were prepared using Pongamia oil, hydrated ethanol and butanol. Out of the six blends of hybrid fuels, the first 3 were blends of CPO while the next 3 were blends of DPO. The designations of these blends are shown in Table 1. For instance, the CPO blend labeled as $\mathrm{E}_{10} \mathrm{~B}_{4} \mathrm{CPO}_{86}$ consisted of $10 \%$ ethanol, $4 \%$ butanol and $86 \%$ CPO (by volume) while the DPO blend labeled as $\mathrm{E}_{9} \mathrm{~B}_{5} \mathrm{DPO}_{86}$, contained 9\% ethanol, 5\% butanol and $86 \%$ DPO (by volume).

The Gross Calorific Value (GCV) was measured using IKA C200 calorimeter and the density was measured using a pycnometer at $21{ }^{\circ} \mathrm{C}$. The kinematic viscosity was measured using a CannonFenske Routine viscometer at $21{ }^{\circ} \mathrm{C}$ and the freezing/melting point was measured using a Perkins Elmer Pyris 6 Differential Scanning Calorimetry (DSC). These fuel characteristics have been shown in Table 1.

The Brake Thermal Efficiency (BTE) and Brake Specific Fuel Consumption (BSFC) of hybrid fuels and neat diesel were tested using Quanchai brand engine coupled with a D-100 water brake dynamometer (electrical - AC). The engine specifications are given in Table 2. The setup had two fuel tanks constructed using measuring cylinders so that the engine could be switched from neat diesel to hybrid fuel during operation. The schematic diagram of the experimental setup is shown in Fig. 1. To carry out the tests, firstly the engine was run using neat diesel to attain its steady state. The engine was then switched to one of the six blends of hybrid fuels and run for at least $1 \mathrm{~min}$ to flush out diesel fuel. To study the engine performance, 5 graduations of load were considered at torques of $0 \mathrm{Nm}$ (zero load), $6 \mathrm{Nm}, 12 \mathrm{Nm}, 18 \mathrm{Nm}$ and $24 \mathrm{Nm}$ (maximum available load). The BSFC was determined using fuel flow rate, which was measured through the technique of constant volume time using a graduated measuring cylinder as a feeder tank. The torque and rpm of the dynamometer were measured by interfacing the dynamometer with Froude Go Power software installed on a desktop computer. Eighteen sets of torque and rpm data were logged by the software at $10 \mathrm{~s}$ intervals for each load and the average values were considered.

To study the emissions of $\mathrm{CO}, \mathrm{NO}_{\mathrm{x}}, \mathrm{CO}_{2}, \mathrm{O}_{2}$ and $\mathrm{SO}_{2}$, a $\mathrm{PG}-250$ model Horiba gas analyzer was utilized. The specifications of the gas analyzer are given in Table 3. The gas analyzer carried out $\mathrm{SO}_{2}$, $\mathrm{CO}, \mathrm{CO}_{2}$ measurements using non dispersive infrared method, $\mathrm{NO}_{\mathrm{x}}$ measurement using chemiluminescence method and $\mathrm{O}_{2}$ measurement using galvanic cell method. The measurement range of $\mathrm{NO}_{\mathrm{x}}$ was from 0 to $2500 \mathrm{ppm}, \mathrm{SO}_{2}$ was from 0 to $1000 \mathrm{ppm}, \mathrm{CO}$ was from 0 to $5000 \mathrm{ppm}, \mathrm{CO}_{2}$ was from 0 to $20 \mathrm{vol} \%$ and $\mathrm{O}_{2}$ was from 0 to 25 vol\%. The measurement error of the gas analyzer was within $\pm 0.5 \%$ of the full scale measurement range. Initially, the gas analyzer went through a warming up process for at least an hour to attain its steady state for stable emissions measurement. Emissions
Table 2

Specifications of the diesel engine used for hybrid fuel tests.

\begin{tabular}{ll}
\hline Model & QC385D \\
\hline Type & Vertical, water cooling, four stroke \\
Combustion Chamber Type & Direct injection \\
Number of Cylinders & 3 \\
Rated output & $9.0 \mathrm{~kW}$ \\
Maximum output & $10.0 \mathrm{~kW}$ \\
Borex Stroke $(\mathrm{mm})$ & $85 \times 90$ \\
Compression Ratio & $18: 1$ \\
Rated Power/speed $(\mathrm{kW} / \mathrm{r} / \mathrm{min})$ & $11 / 1500$ \\
Starting Method & Electric \\
\hline
\end{tabular}

from the engine were detected by inserting the gas analyzer probe in the exhaust pipe. The exhaust emissions of all the six blends and neat diesel were measured at 5 graduations of loads, from zero to maximum available load.

\section{Results and discussion}

\subsection{Crude and degummed pongamia oil - ethanol microemulsions}

Both the CPO and DPO hybrid fuel blends form homogeneous mixtures with ethanol up to $9 \%$ (by volume). At higher percentages, the use of surfactant becomes vital because ethanol phase separates from Pongamia oil due to polar nature of the former and nonpolar nature of the latter.

The ternary phase diagrams presented in Fig. 2 and Fig. 3 show the miscibility of hydrated ethanol (95\%) in CPO and in DPO, respectively, using butanol as a surfactant. The region above the miscibility curve represents miscible and stable blends of hybrid fuels $[33,34]$. The region below the miscibility curve represents unstable blends of hybrid fuel, which were cloudy in appearance or would phase separate. The blends of hybrid fuels that lie on the miscibility curve chiefly represent those miscible hybrid fuels which can be blended with minimum requirement of butanol surfactant. The 6 blends of hybrid fuels prepared using CPO and DPO falls on the miscibility curve. The shaded area ABCD and EFGH in the ternary diagram represents the approximate domain for CPO and DPO hybrid fuel formulations respectively [33], which are within the scope of this study.

According to Fig. 2, the peak miscibility for CPO blends were achieved at approximately 20\% CPO, 48\% ethanol and 32\% butanol. According to Fig. 3, the peak miscibility for DPO blends were achieved at approximately $22 \% \mathrm{DPO}, 43 \%$ ethanol and $35 \%$ butanol. This shows that slightly more surfactant is required for blending ethanol in DPO hybrid fuels than in CPO hybrid fuels. Furthermore, the ternary curve for DPO hybrid fuel blends shows greater area below the curve, thus depicting more unstable and immiscible blends in comparison with CPO hybrid fuel blends. The observations indicate

Table 1

Fuel characteristics of Pongamia hybrid fuels, its constituents and diesel.

\begin{tabular}{|c|c|c|c|c|c|}
\hline Fuel & Gross calorific value (MJ kg $\left.{ }^{-1}\right)$ & Density at $21^{\circ} \mathrm{C}\left(\mathrm{g} \mathrm{cm}^{-3}\right)$ & Kinematic viscosity at $21^{\circ} \mathrm{C}(\mathrm{cSt})$ & Freezing point $\left({ }^{\circ} \mathrm{C}\right)$ & Melting Point $\left({ }^{\circ} \mathrm{C}\right)$ \\
\hline $\mathrm{E}_{10} \mathrm{~B}_{4} \mathrm{CPO}_{86}$ & 38.23 & 0.901 & 48.73 & -8.777 & -6.375 \\
\hline $\mathrm{E}_{17} \mathrm{~B}_{14} \mathrm{CPO}_{69}$ & 36.78 & 0.882 & 21.24 & -10.977 & -7.845 \\
\hline $\mathrm{E}_{23} \mathrm{~B}_{25} \mathrm{CPO}_{52}$ & 35.79 & 0.864 & 13.51 & -9.021 & -7.312 \\
\hline $\mathrm{E}_{9} \mathrm{~B}_{5} \mathrm{DPO}_{86}$ & 38.04 & 0.897 & 36.66 & -4.654 & -7.510 \\
\hline $\mathrm{E}_{17} \mathrm{~B}_{16} \mathrm{DPO}_{67}$ & 36.77 & 0.876 & 19.20 & -6.914 & -2.080 \\
\hline $\mathrm{E}_{22} \mathrm{~B}_{27} \mathrm{DPO}_{51}$ & 35.92 & 0.862 & 13.04 & -6.291 & -1.863 \\
\hline $\mathrm{CPO}$ & 39.27 & 0.922 & 92.13 & -4.277 & -5.543 \\
\hline DPO & 38.46 & 0.920 & 90.64 & -2.977 & -6.844 \\
\hline Diesel & 45.63 & 0.838 & 5.86 & - & - \\
\hline Hydrated Ethanol (95\% purity) & 28.64 & 0.788 & 2.11 & - & - \\
\hline Butanol & 20.36 & 0.807 & 3.59 & - & - \\
\hline
\end{tabular}




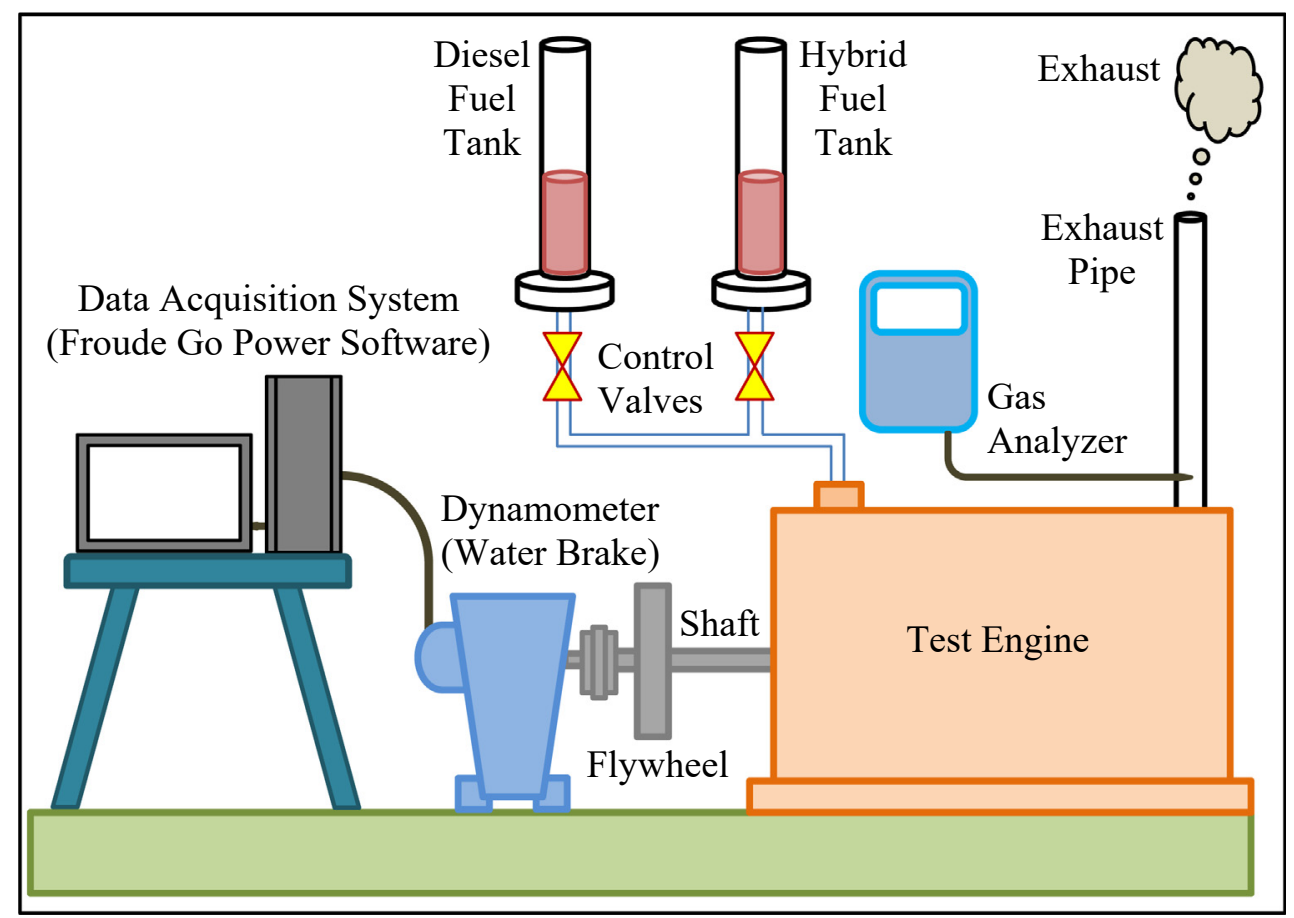

Fig. 1. Schematic diagram for the experimental set up of hybrid fuel tests and emissions analysis.

Table 3

Specifications of Horiba portable gas analyzer used for emissions analysis.

\begin{tabular}{ll}
\hline Model & $\mathrm{PG}-250$ \\
\hline Emissions Measured & $\mathrm{NO}_{x}, \mathrm{SO}_{2}, \mathrm{CO}, \mathrm{CO}_{2}$ and $\mathrm{O}_{2}$ \\
Measuring Principle & $\mathrm{NO}: \mathrm{Chemiluminescence} \mathrm{method}$ \\
& $\mathrm{SO}_{2}, \mathrm{CO}, \mathrm{CO}_{2}:$ Non dispersive infrared method \\
& $\mathrm{O}_{2}:$ Galvanic cell method \\
& $\mathrm{NO}_{\mathrm{x}}: 0-2500 \mathrm{ppm}$ \\
Measurement Range & $\mathrm{SO}_{2}: 0-1000 \mathrm{ppm}$ \\
& $\mathrm{CO}_{0} 0-5000 \mathrm{ppm}$ \\
& $\mathrm{CO}_{2}: 0$ to $20 \mathrm{vol} \%$ \\
& $\mathrm{O}_{2}: 0$ to $25 \mathrm{vol} \%$ \\
Repeatability & within $\pm 0.5 \%$ of full scale \\
Linearity & within $\pm 2.0 \%$ of full scale \\
Response speed & Within $45 \mathrm{~s}$ \\
Output & 4 mA-20 mA DC (non-insulation signal) \\
Cell extracting flow rate & Approximately $0.4 \mathrm{~L} /$ min \\
Ambient temperature range & $5{ }^{\circ} \mathrm{C}$ to $40{ }^{\circ} \mathrm{C}$ \\
Ambient humidity range & maximum $80 \%$ \\
\hline
\end{tabular}

that DPO is more non-polar than CPO and the former requires more surfactant for the miscibility of polar ethanol.

\subsection{Hybrid fuel characteristics}

The fuel characteristics of hybrid fuels, diesel, CPO, DPO as well as ethanol and butanol are given in Table 1 .

The GCV of a biofuel is an important fuel characteristic that represents the amount of heat transferred to the chamber of a $\mathrm{CI}$ engine during the process of combustion. According to the table, the comparisons reveal that generally $\mathrm{CPO}$ hybrid fuel blends have slightly higher GCV than DPO hybrid fuel blends. However, all the hybrid fuel blends show slightly lower GCV than diesel, merely due to lower GCV of ethanol, butanol and CPO or DPO in the blends. The GCVs of $\mathrm{E}_{10} \mathrm{~B}_{4} \mathrm{CPO}_{86}$ and $\mathrm{E}_{9} \mathrm{~B}_{5} \mathrm{DPO}_{86}$ are $16.22 \%$ and $16.63 \%$ lower than diesel, respectively. Yet, the GCVs of all the blends of hybrid fuels are higher than $35.79 \mathrm{MJ} / \mathrm{kg}$. The GCVs of CPO and DPO are
$13.94 \%$ and $15.71 \%$ lower than diesel, respectively. The GCVs of CPO and DPO hybrid fuel blends are generally lower than the GCVs of CPO and DPO, respectively, due to lower GCVs of ethanol and butanol present in the hybrid fuel blends. The GCV of ethanol is $27.07 \%$ and $25.53 \%$ lower than the GCVs of CPO and DPO, respectively. The GCV of butanol is $48.15 \%$ and $47.06 \%$ lower than the GCVs of CPO and DPO, respectively. Hybrid fuels with high GCV or heating value are given higher preferences as they have more energy content to operate diesel engines with less fuel consumption.

Densities of DPO hybrid fuel blends are slightly lower than the densities of CPO hybrid fuel blends due to slightly lower density of DPO than CPO. Densities of hybrid fuels are slightly higher than diesel. As the percentage composition of ethanol and butanol increases in CPO and DPO, the density of hybrid fuels decreases due to lower densities of butanol and ethanol. The DPO hybrid fuel blends show more suitability for $\mathrm{CI}$ engines as they have low densities, which are closer to the density of diesel.

The kinematic viscosity of DPO is lower than that of CPO. This leads to lower viscosity of DPO hybrid fuel blends in comparison with CPO hybrid fuel blends. The increase in percentage composition of ethanol and butanol in CPO and DPO, respectively, decreases the viscosity of hybrid fuel blends. Viscosities of $\mathrm{E}_{23} \mathrm{~B}_{25} \mathrm{CPO}_{52}$ and $\mathrm{E}_{22} \mathrm{~B}_{27} \mathrm{DPO}_{51}$ are $13.51 \mathrm{cSt}$ and $13.04 \mathrm{cSt}$, respectively, which are close to the viscosity of diesel. Generally, the low viscosities of DPO hybrid fuel blends make such fuels more suitable in diesel engines due to better fuel atomization and combustion which prevents piston ring sticking, injector cocking, injector deposits, fuel system clogging and injector pump failure. Furthermore, the viscosity and density parameters have been found to correlate. The dependence of density with (kinematic viscosity $)^{-1 / 2}$ for CPO and DPO hybrid fuel blends shown in Fig. 4 indicate that the densities of hybrid fuels are good estimators of their kinematic viscosities [35]. The correlation indicates the accuracy in determining the viscosities and densities. Viscosities and densities of DPO hybrid fuels are lower and more close to diesel, which makes them more suitable for $\mathrm{CI}$ engine without any engine modification. 


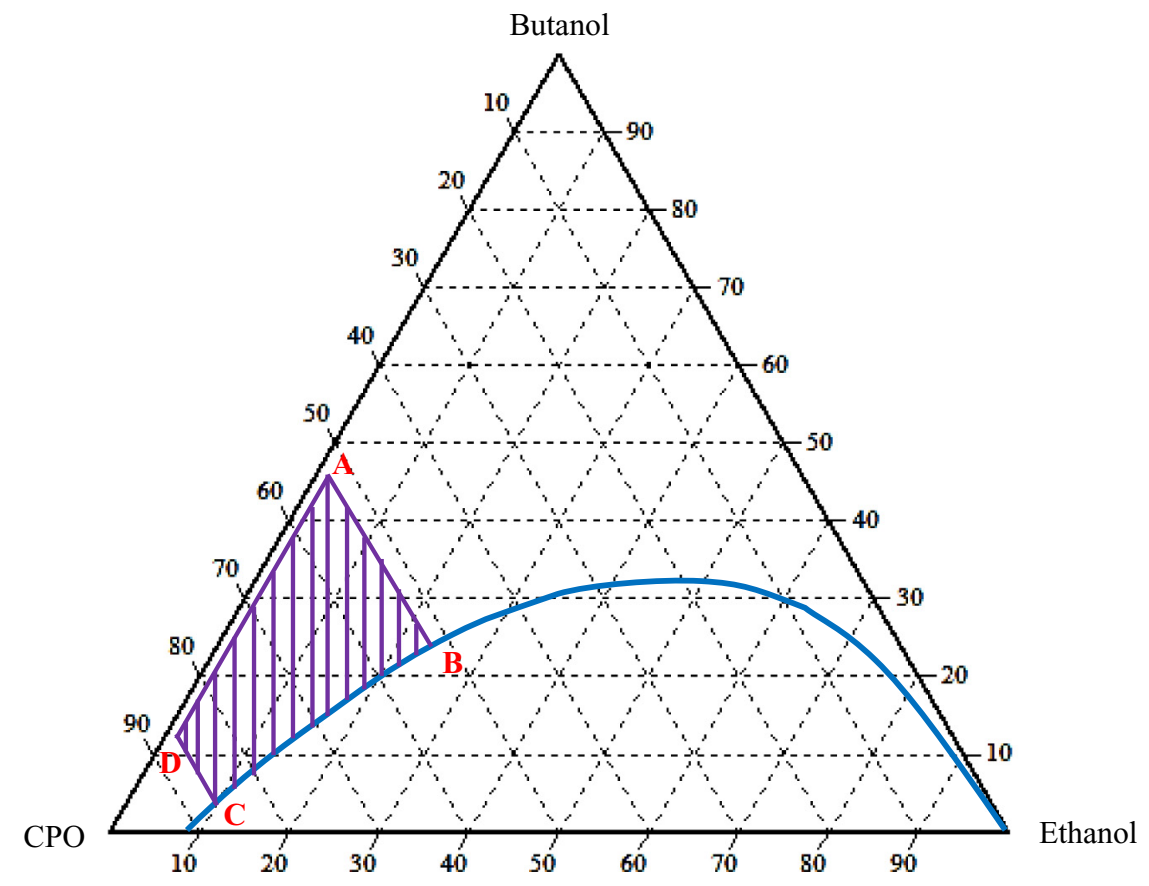

Fig. 2. Ternary phase diagram describing the phase behavior for the system of crude Pongamia oil, hydrated ethanol (95\% purity) and butanol microemulsions at $29{ }^{\circ} \mathrm{C}$.

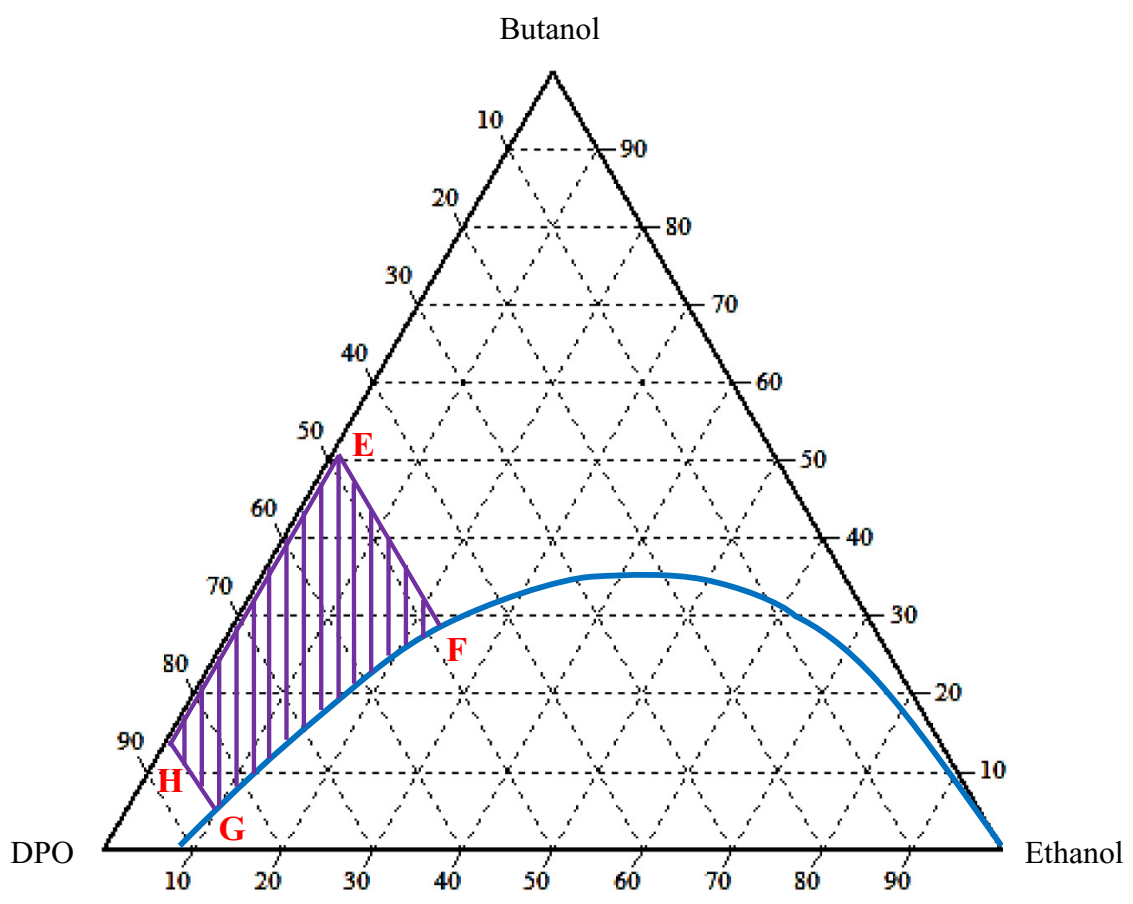

Fig. 3. Ternary phase diagram describing the phase behavior for the system of degummed Pongamia oil, hydrated ethanol ( $95 \%$ purity) and butanol microemulsions, at $29{ }^{\circ} \mathrm{C}$.

Freezing points of all the hybrid fuels are lower than $-4.654{ }^{\circ} \mathrm{C}$. The CPO hybrid fuel blends show lower melting and freezing points than DPO hybrid fuel blends. Such trend is due to low freezing and melting points of CPO in comparison with DPO. The trends of melting/freezing points indicate the suitability of hybrid fuels for countries with tropical climates in the South Pacific.

\subsection{Performance analysis on CI engine}

Fig. 5 and Fig. 6 show graphs of BTE against load for CPO hybrid fuel blends and DPO hybrid fuel blends, respectively. As anticipated, the $\mathrm{BTE}$ of $\mathrm{CI}$ engine increases with increasing load. The efficiency versus load curves shows highest level of engine efficiency with $\mathrm{E}_{17} \mathrm{~B}_{14} \mathrm{CPO}_{69}$ 


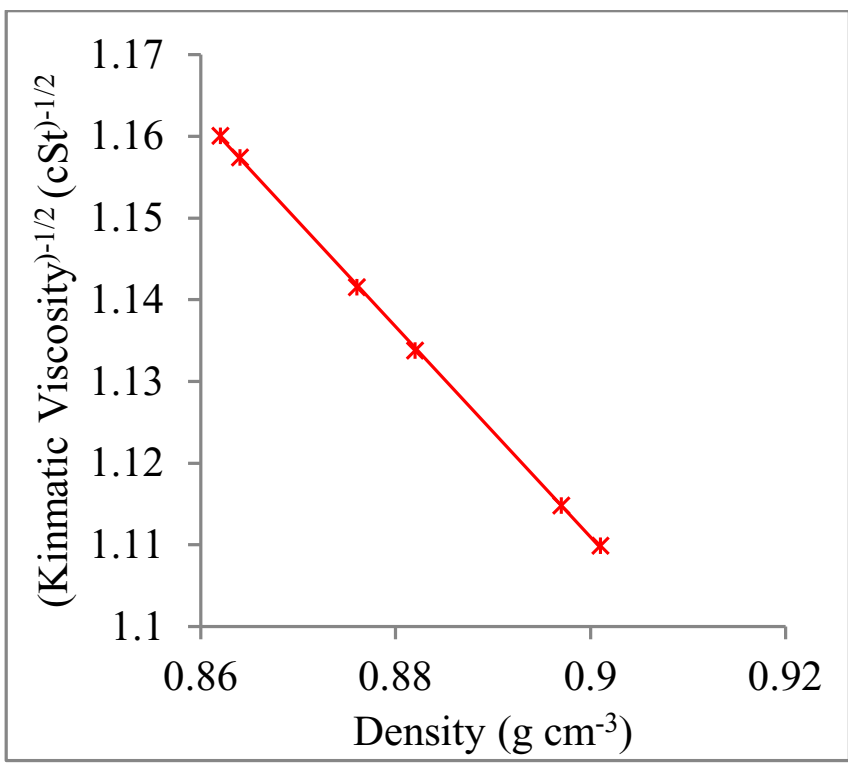

Fig. 4. Dependence of density with (kinematic viscosity $)^{-1 / 2}$ for crude Pongamia oil and degummed Pongamia oil hybrid fuel blends, which indicates that densities of hybrid fuels are good estimators of their kinematic viscosities.

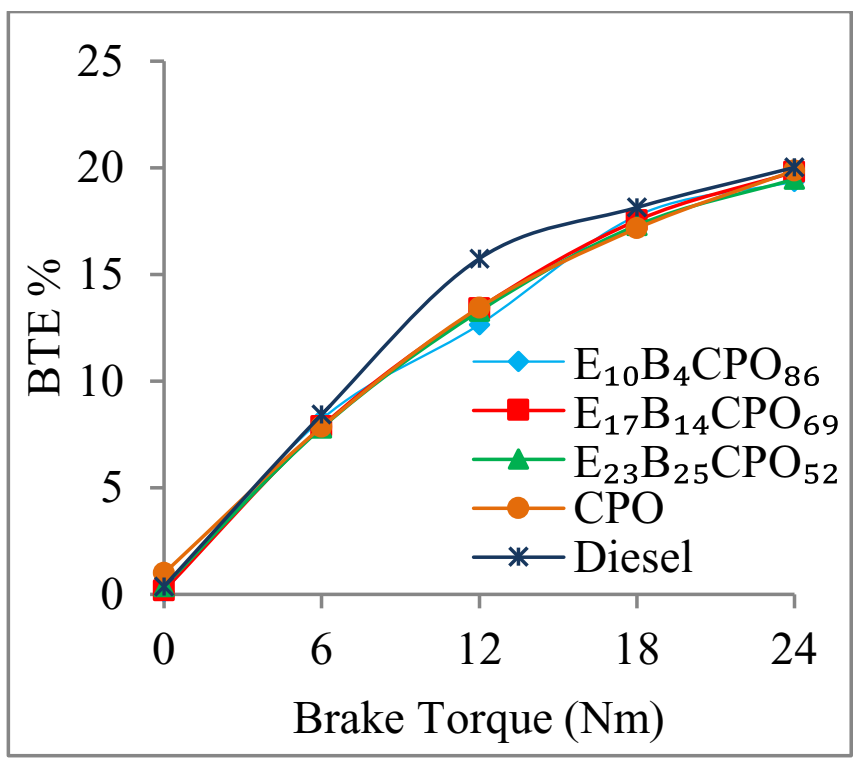

Fig. 5. Brake thermal efficiency variations with load for crude Pongamia oil based hybrid fuel blends, crude Pongamia oil and diesel.

and $\mathrm{E}_{17} \mathrm{~B}_{16} \mathrm{DPO}_{67}$. The performances of all the blends of hybrid fuel are comparable with diesel. The maximum diesel engine efficiencies of all hybrid fuels, i.e. $\mathrm{E}_{10} \mathrm{~B}_{4} \mathrm{CPO}_{86}, \mathrm{E}_{17} \mathrm{~B}_{14} \mathrm{CPO}_{69}, \mathrm{E}_{23} \mathrm{~B}_{25} \mathrm{CPO}_{52}, \mathrm{E}_{9} \mathrm{~B}_{5} \mathrm{DPO}_{86}$, $\mathrm{E}_{17} \mathrm{~B}_{16} \mathrm{DPO}_{67}$ and $\mathrm{E}_{22} \mathrm{~B}_{27} \mathrm{DPO}_{51}$ are $3.30 \%, 1.05 \%, 2.75 \%, 5.94 \%, 3.40 \%$ and $5.84 \%$ less than unblended diesel, respectively. The efficiencies using hybrid fuels are slightly lower than diesel due to their lower volatility, led by slightly higher viscosity and density. Higher viscosity of fuel influences injection characteristics due to larger fuel droplets and reduces the engine efficiency [36]. Generally, the engine efficiencies of hybrid fuels are very similar to diesel fuel at all loads. However, slightly lower viscosity of DPO hybrid fuel blends makes them more suitable for $\mathrm{CI}$ engine.

Fig. 7 and Fig. 8 show graphs of BSFC against load for CPO hybrid fuel blends and DPO hybrid fuel blends, respectively. Generally, the

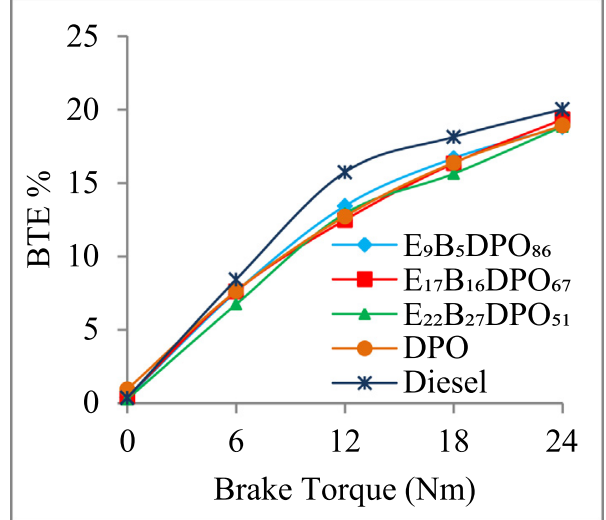

Fig. 6. Brake thermal efficiency variations with load for degummed Pongamia oil based hybrid fuel blends, degummed Pongamia oil and diesel.

results for BSFC further validate the exemplifications of BTE against load graphs. The fuel consumption per unit of output power produced by diesel engine decreases with increasing load for all hybrid fuel blends, as well as for CPO, DPO and diesel. Diesel shows the lowest BSFC at all loads. However, amongst the CPO hybrid fuel blends, $\mathrm{E}_{10} \mathrm{~B}_{4} \mathrm{CPO}_{86}$ and $\mathrm{E}_{17} \mathrm{~B}_{14} \mathrm{CPO}_{69}$ show lower $\mathrm{BSFC}$, while amongst the DPO hybrid fuel blends, lower BSFC is shown by $\mathrm{E}_{9} \mathrm{~B}_{5} \mathrm{DPO}_{86}$ and $\mathrm{E}_{17} \mathrm{~B}_{16} \mathrm{DPO}_{67}$. Such trend is obtained due to lower GCVs of hybrid fuels in comparison with diesel. Generally, as the GCV of fuels decreases, the BSFC increases to meet the output power demand of the load. Thus, slightly more hybrid fuel would be required to produce $1 \mathrm{~kW}$ of power in an hour at any load in comparison with diesel fuel.

\subsection{Hybrid fuel emissions characteristics}

Fig. 9 and Fig. 10 show the emissions characteristic of $\mathrm{CO}_{2}$ with increasing load. The $\mathrm{CO}_{2}$ emissions of hybrid fuels, $\mathrm{CPO}$ and DPO are mostly lower than diesel fuel. Generally, the $\mathrm{CO}_{2}$ emissions of DPO hybrid fuel blends are lower in comparison with $\mathrm{CPO}$ blends. $\mathrm{CO}_{2}$ is formed during the combustion of hybrid fuels. Complete oxidation

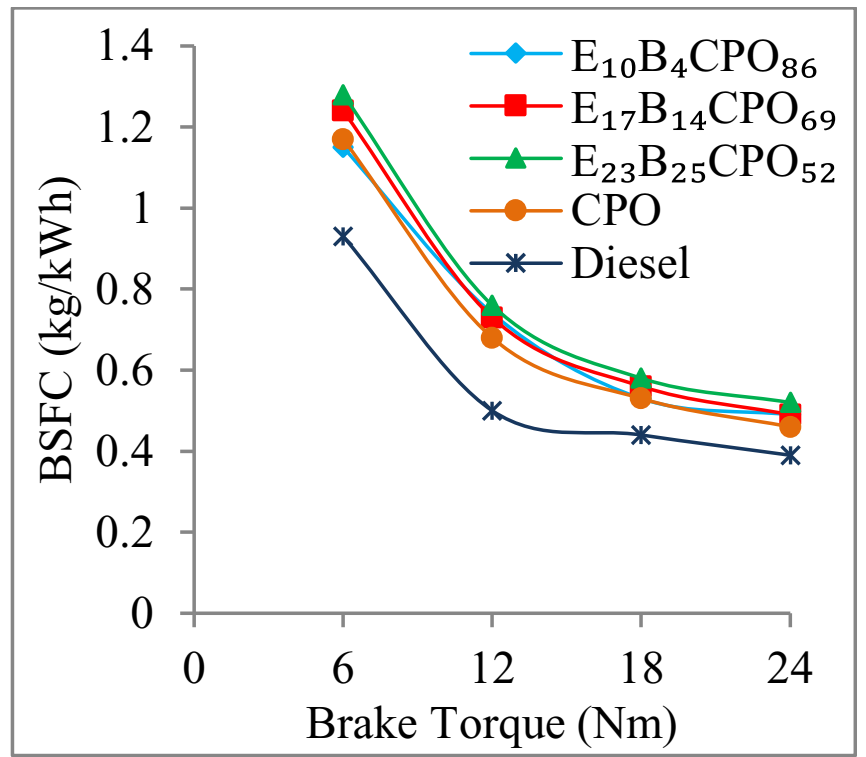

Fig. 7. Brake specific fuel consumption variations with load for crude Pongamia oil based hybrid fuel blends, crude Pongamia oil and diesel. 


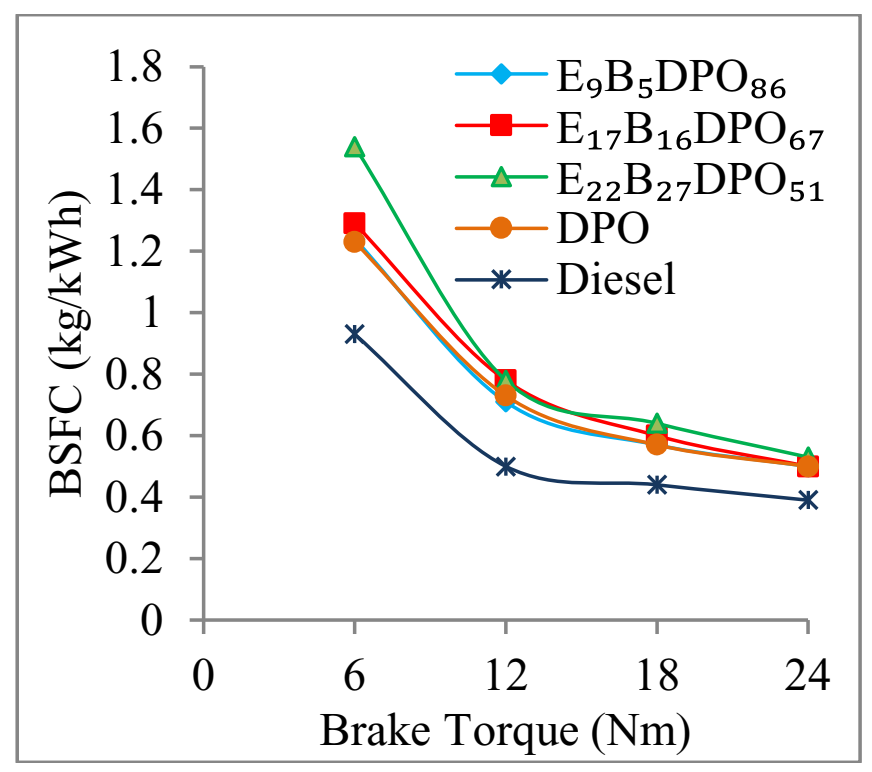

Fig. 8. Brake specific fuel consumption variations with load for degummed Pongamia oil based hybrid fuel blends, degummed Pongamia oil and diesel.

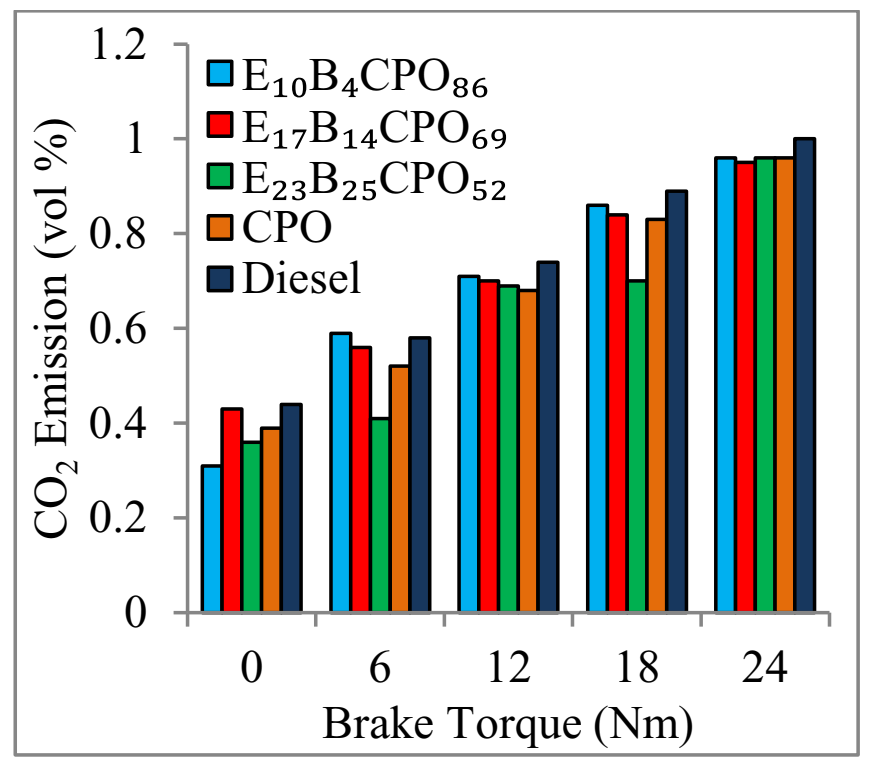

Fig. 9. The $\mathrm{CO}_{2}$ emissions of crude Pongamia oil based hybrid fuel blends, crude Pongamia oil and diesel.

of simple hydrocarbon fuels during combustion forms $\mathrm{CO}_{2}$ from all of the carbon and water from the hydrogen [37]. At maximum load, the $\mathrm{CO}_{2}$ emissions of $\mathrm{E}_{22} \mathrm{~B}_{27} \mathrm{DPO}_{51}, \mathrm{E}_{23} \mathrm{~B}_{25} \mathrm{CPO}_{52}$ and $\mathrm{E}_{17} \mathrm{~B}_{16} \mathrm{DPO}_{67}$ were reduced by $4 \%, 9 \%$ and $11 \%$, respectively, when compared to diesel. These blends of hybrid fuels show reduced $\mathrm{CO}_{2}$ emissions due to increasing percentage composition of ethanol in the blends. The use of hybrid fuel minimizes $\mathrm{CO}_{2}$ emissions, thus reducing the Global Warming Potentials (GWPs).

Fig. 11 and Fig. 12 show the emissions characteristic of $\mathrm{NO}_{\mathrm{x}}$ with increasing load. The $\mathrm{NO}_{\mathrm{x}}$ emissions of hybrid fuels, $\mathrm{CPO}$ and DPO are lower than diesel fuel. Generally, the $\mathrm{NO}_{\mathrm{x}}$ emissions of DPO hybrid fuel blends are lower in comparison with $\mathrm{CPO}$ blends. $\mathrm{NO}_{\mathrm{x}}$ emissions are noticeable although there are no nitrogen compounds present in CPO and DPO hybrid fuel blends with ethanol and butanol surfactant. Nitrogen is already present in the volume of air

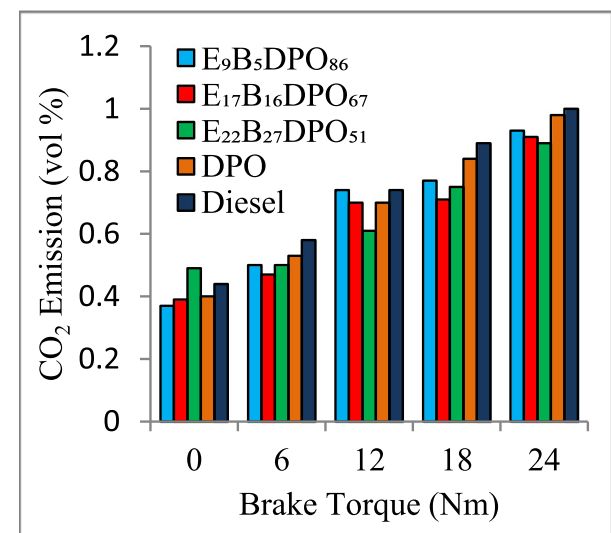

Fig. 10. The $\mathrm{CO}_{2}$ emissions of degummed Pongamia oil based hybrid fuel blends, degummed Pongamia oil and diesel.

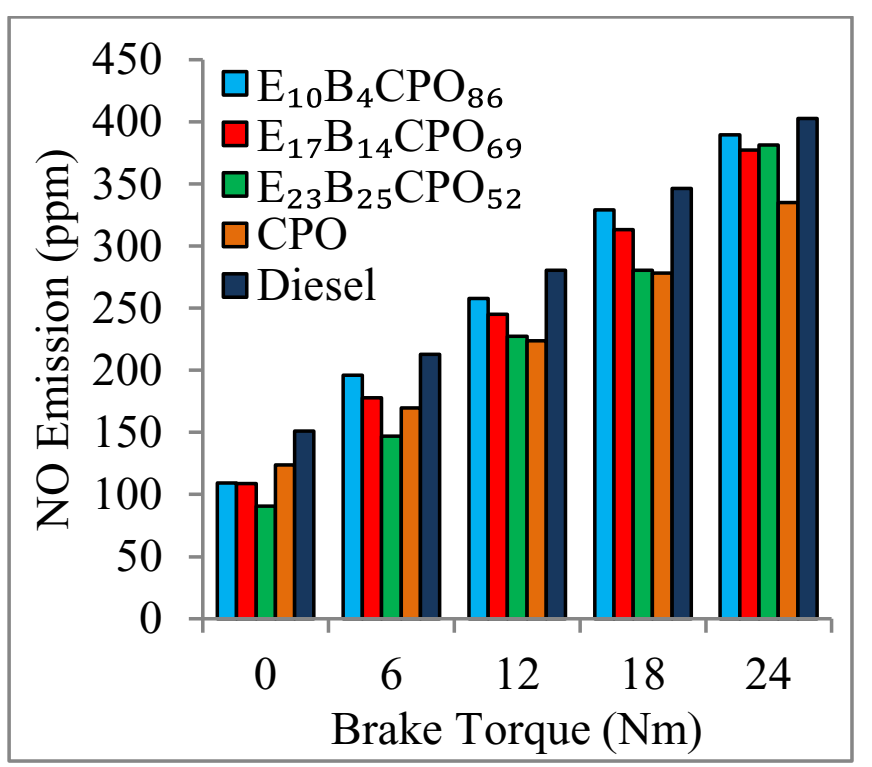

Fig. 11. The NO emissions of crude Pongamia oil based hybrid fuel blends, crude Pongamia oil and diesel.

intake and during the combustion of fuel at high temperatures, $\mathrm{NO}_{\mathrm{x}}$ is formed as an exhaust emission [38]. At maximum load, the NO emissions of $\mathrm{E}_{22} \mathrm{~B}_{27} \mathrm{DPO}_{51}, \mathrm{E}_{23} \mathrm{~B}_{25} \mathrm{CPO}_{52}$ and $\mathrm{E}_{17} \mathrm{~B}_{16} \mathrm{DPO}_{67}$ were reduced by $11.20 \%, 5.27 \%$ and $14.24 \%$, respectively, when compared to diesel. Hydrated ethanol (5\% water) was used to serve as a heat sink and to lower the combustion temperature to reduce $\mathrm{NO}_{\mathrm{x}}$ and smoke emissions [33]. The use of hybrid fuels minimizes $\mathrm{NO}_{\mathrm{x}}$ emissions, thus reducing the Eutrophication Potentials (EPs).

Fig. 13 and Fig. 14 show the emissions characteristic of $\mathrm{CO}$ with increasing load. The CO emissions of all hybrid fuel blends, CPO and DPO are higher than diesel fuel. Generally, the CO emissions of CPO hybrid fuel blends are slightly lower in comparison with DPO blends. The $\mathrm{CO}$ gas is produced when fuels burn with incomplete combustion in presence of insufficient $\mathrm{O}_{2}[39,40]$. The low $\mathrm{O}_{2}$ to fuel ratio is common mostly during engine starting and more $\mathrm{CO}$ gas is emitted at this instance. At maximum load, the $\mathrm{CO}$ emissions of $\mathrm{E}_{22} \mathrm{~B}_{27} \mathrm{DPO}_{51}, \mathrm{E}_{23} \mathrm{~B}_{25} \mathrm{CPO}_{52}$ and $\mathrm{E}_{17} \mathrm{~B}_{16} \mathrm{DPO}_{67}$ are increased by $25.26 \%, 30.57 \%$ and $72.12 \%$, respectively, when compared to diesel.

Fig. 15 and Fig. 16 show the emissions characteristic of $\mathrm{SO}_{2}$ with increasing load. The $\mathrm{SO}_{2}$ emissions from hybrid fuels, CPO and DPO are very low. The maximum $\mathrm{SO}_{2}$ emission has been recorded to be 


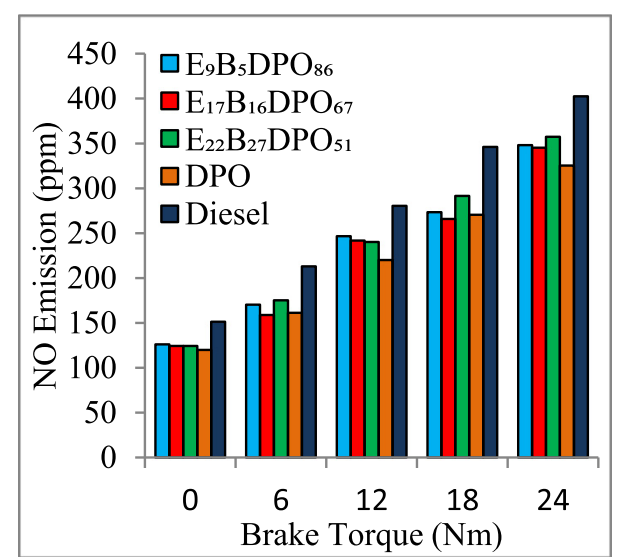

Fig. 12. The NO emissions of degummed Pongamia oil based hybrid fuel blends, degummed Pongamia oil and diesel.

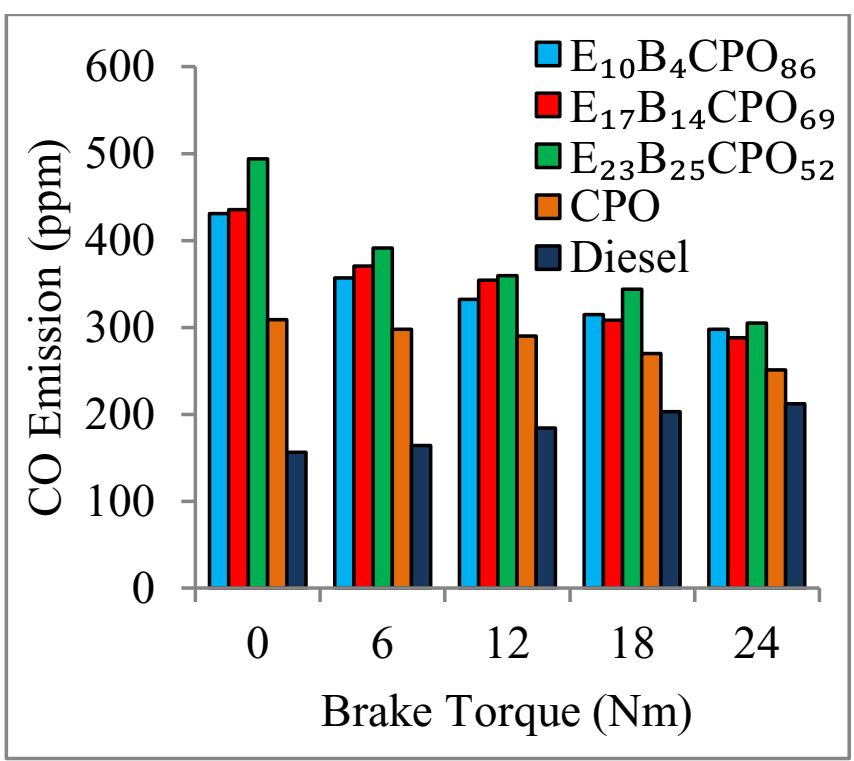

Fig. 13. The $\mathrm{CO}$ emissions of crude Pongamia oil based hybrid fuel blends, crude Pongamia oil and diesel.

9.1 ppm. Although $\mathrm{SO}_{2}$ emissions from $\mathrm{CPO}$ hybrid fuel blends are bit higher than diesel, it is interesting to note that DPO hybrid fuel blends have lower $\mathrm{SO}_{2}$ emissions than diesel at loads with brake torque greater than $12 \mathrm{~N} / \mathrm{m}$. At maximum load, the $\mathrm{SO}_{2}$ emissions of $\mathrm{E}_{22} \mathrm{~B}_{27} \mathrm{DPO}_{51}$ and $\mathrm{E}_{17} \mathrm{~B}_{16} \mathrm{DPO}_{67}$ were reduced by $8.57 \%$ and $14.29 \%$, respectively, when compared to diesel. The use of DPO hybrid fuels minimizes $\mathrm{SO}_{2}$ emissions, thus reducing the Acidification Potentials (APs).

Fig. 17 shows the emissions characteristic of the best performing blend of hybrid fuel $\left(\mathrm{E}_{17} \mathrm{~B}_{16} \mathrm{DPO}_{67}\right)$ prepared by degumming Pongamia oil. At maximum load, the emissions characteristics show $345.2 \mathrm{ppm}$ of $\mathrm{NO}$ emission, $293.8 \mathrm{ppm}$ of $\mathrm{CO}$ emission, $6 \mathrm{ppm}$ of $\mathrm{SO}_{2}$ emission and $0.91 \mathrm{vol} \%$ of $\mathrm{CO}_{2}$ emission. In comparison with diesel, the $\mathrm{CO}_{2}$ emission reduced by $11 \%$, NO emissions reduced by $14.24 \%$ and $\mathrm{SO}_{2}$ emissions reduced by $14.29 \%$.

\subsection{Environmental impact of $\mathrm{CO}_{2}$ emissions from the whole life cycle of hybrid fuel production}

Production of Pongamia - ethanol hybrid fuel is an advantage

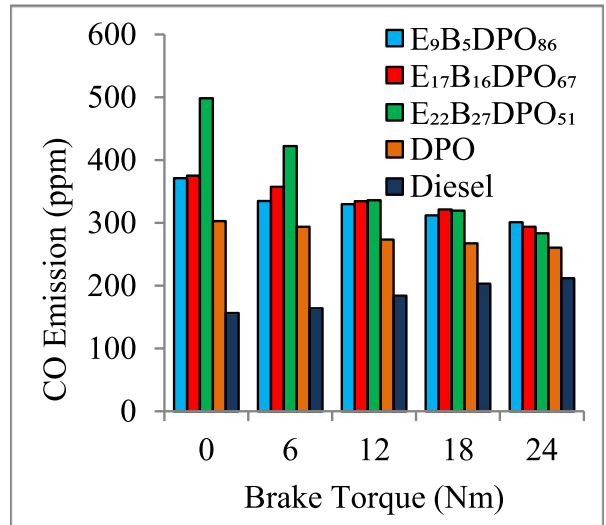

Fig. 14. The CO emissions of degummed Pongamia oil based hybrid fuel blends degummed Pongamia oil and diesel.

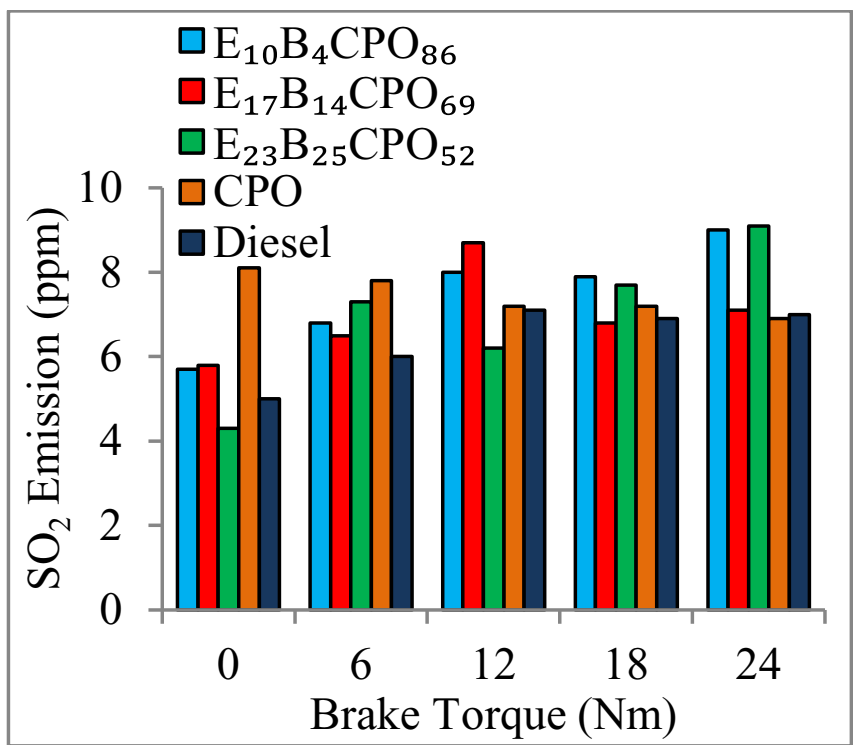

Fig. 15. The $\mathrm{SO}_{2}$ emissions of crude Pongamia oil based hybrid fuel blends, crude Pongamia oil and diesel.

for the PICs, as both its components (Pongamia oil and ethanol) can be produced indigenously, thus providing huge savings in foreign exchange for the country, as well as contributing to the cause of emissions reduction. The tropical nature of most PICs, such as Fiji, makes them suitable for producing Pongamia oil from Pongamia plantations and bio-ethanol from sugarcane, as such plantations currently exist in Fiji and are renewable sources of hybrid fuel feedstock.

Vegetable oils are inherently carbon-neutral. This means that all the carbon, in the form of $\mathrm{CO}_{2}, \mathrm{CO}$ and Carbon $(\mathrm{C})$ produced during their combustion was originally extracted from the atmosphere through the process of photosynthesis [41]. However, the process of their production and transportation invariably involves the use of petroleum-based fuels, which emit $\mathrm{CO}_{2}$ to the atmosphere and produce a net contribution to carbon emissions. To assess how significant these emissions are at each stage of the oil production and transportation process requires a full LCIA.

As Pongamia oil is the major feedstock for producing the hybrid fuel studied, it is important to carry out an LCIA based on this constituent of the hybrid fuel production. The system boundary of the production cycle is divided into three major stages, as shown in 


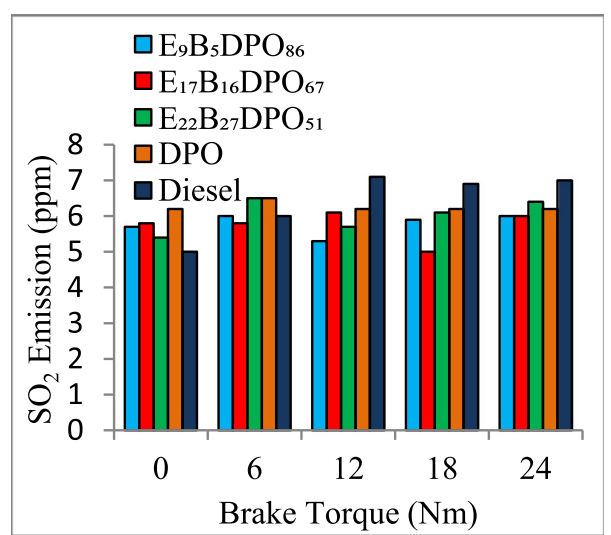

Fig. 16. The $\mathrm{SO}_{2}$ emissions of degummed Pongamia oil based hybrid fuel blends, degummed Pongamia oil and diesel.

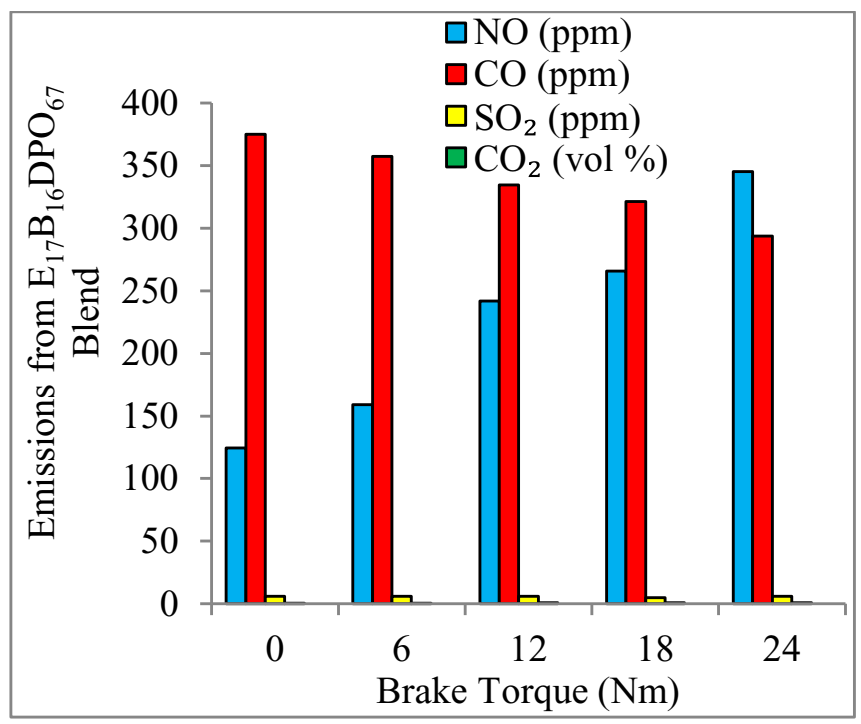

Fig. 17. Emissions of $\mathrm{NO}, \mathrm{CO}, \mathrm{SO}_{2}$ and $\mathrm{CO}_{2}$ from $\mathrm{E}_{17} \mathrm{~B}_{16} \mathrm{DPO}_{67}$ blend.
Fig. 18. The first stage involves Pongamia cultivation (plantation, nurturing and harvest), where the inputs are Pongamia seeds, polybags, organic fertilizer, glyphosate and diesel for seed transport, irrigating, seedling transport, fertilizer transport, glyphosate transport, and Pongamia pod transport. The second stage involves Pongamia oil production (crude Pongamia oil extraction and refining/degumming), where the inputs are $\mathrm{NaOH}$, electricity, $\mathrm{H}_{3} \mathrm{PO}_{4}$ and water. The third stage involves Pongamia - ethanol hybrid fuel production, where the inputs are refined Pongamia oil, ethanol, butanol, electricity and diesel for hybrid fuel transport. A life cycle inventory for such inputs and outputs of Pongamia farming, Pongamia oil production, refining/degumming and hybrid fuel production is compiled in Table 4. The functional unit utilized in the analysis is MJ of energy from Pongamia - ethanol hybrid fuel. The assessment is carried out for $\mathrm{E}_{17} \mathrm{~B}_{16} \mathrm{DPO}_{67}$ blend of hybrid fuel with energy content (GCV) of $36.77 \mathrm{MJ} / \mathrm{kg}$. Using the life cycle inventory data, a life cycle impact assessment is carried out for $\mathrm{CO}_{2}$ emissions per MJ of energy from Pongamia - ethanol hybrid fuel, as shown in Table 5 . The $\mathrm{CO}_{2}$ emissions are determined by considering the product of the quantity and emissions factor of the input [42-49]. The environmental impact analysis of the life cycle production of Pongamia hybrid fuel shows emissions of $6.05 \mathrm{~g} \mathrm{CO}_{2} \mathrm{eq} /$ $\mathrm{MJ}$ of hybrid fuel. In comparison with the production of diesel fuel, which produces 7.9-24 $\mathrm{g} \mathrm{CO}_{2} \mathrm{eq} / \mathrm{MJ}$ of diesel fuel [50], hybrid fuel production shows reduced emissions of $\mathrm{CO}_{2}$.

\section{Conclusion}

The GCVs of hybrid fuels are close to that of diesel and the freezing points are up to $-4.654{ }^{\circ} \mathrm{C}$, which allows the fuel to be utilized at lower temperatures. The viscosities of CPO and DPO are reduced by blending with ethanol and butanol and the fuel can be utilized on $\mathrm{Cl}$ engine without any further modifications. Hybrid fuel blend formulations by degumming Pongamia oil shows slightly reduced viscosity in comparison with hybrid fuel blends of CPO. The BTE of hybrid fuels on CI engine are similar to that of diesel; however, the former show slightly higher BSFC due to their lower GCVs. The blends of $\mathrm{E}_{22} \mathrm{~B}_{27} \mathrm{DPO}_{51}$ and $\mathrm{E}_{17} \mathrm{~B}_{16} \mathrm{DPO}_{67}$ prepared by degumming Pongamia oil show similar performance to diesel fuel, as the maximum diesel engine efficiencies for such blends are only

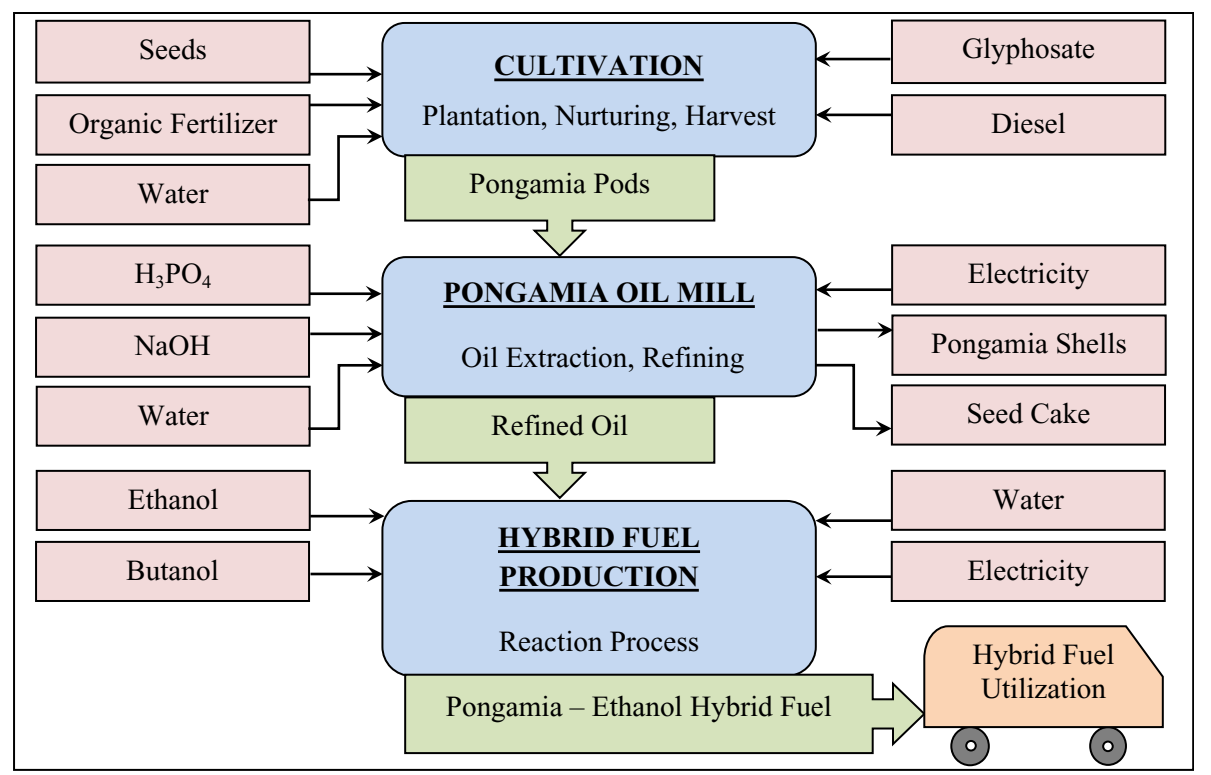

Fig. 18. System boundary for Pongamia hybrid fuel production. 
Table 4

Life cycle inventory for inputs and outputs of Pongamia - ethanol hybrid fuel production

\begin{tabular}{|c|c|c|c|}
\hline Stages & \multicolumn{2}{|c|}{ Amount (/L Hybrid Fuel) } & Amount (/MJ) \\
\hline \multicolumn{4}{|l|}{ Pongamia Cultivation } \\
\hline \multicolumn{4}{|l|}{ Input } \\
\hline Seeds (kg) & 0.0002 & 7.60E-06 & \\
\hline Polybags (kg) & 0.0004 & $1.19 \mathrm{E}-05$ & \\
\hline Organic fertilizer $(\mathrm{kg})$ & 0.1570 & 4.78E-03 & \\
\hline Diesel (water pump - irrigating seedlings) (km) & 0.0000 & 2.43E-08 & \\
\hline Glyphosate (L) & 0.0005 & $1.53 \mathrm{E}-05$ & \\
\hline Diesel (truck round trip - seed transport) (km) & 0.0000 & $1.83 \mathrm{E}-07$ & \\
\hline Diesel (truck round trip - seedling transport) (km) & 0.0002 & $5.06 \mathrm{E}-06$ & \\
\hline Diesel (truck round trip - fertilizer transport) $(\mathrm{km})$ & 0.0011 & 3.38E-05 & \\
\hline Diesel (truck round trip - glyphosate transport) (km) & 0.0000 & $1.01 \mathrm{E}-06$ & \\
\hline Diesel (truck round trip - Pongamia pod transport) $(\mathrm{km})$ & 0.0823 & $2.51 \mathrm{E}-03$ & \\
\hline \multicolumn{4}{|l|}{ Output } \\
\hline Harvested seeds ( $\mathrm{kg}$ ) & 3.1080 & $9.46 \mathrm{E}-02$ & \\
\hline \multicolumn{4}{|l|}{ Pongamia Oil Extraction and Refining } \\
\hline Electricity (kWh) & 0.0744 & & $2.26 \mathrm{E}-03$ \\
\hline $\mathrm{H}_{3} \mathrm{PO}_{4}$ (oil refining) $(\mathrm{kg})$ & 0.0010 & & 2.93E-05 \\
\hline $\mathrm{NaOH}$ (acid neutralizing) (kg) & 0.0029 & & $8.80 \mathrm{E}-05$ \\
\hline Water $(\mathrm{L})$ & 0.0522 & & $1.59 \mathrm{E}-03$ \\
\hline \multicolumn{4}{|l|}{ Output } \\
\hline Pongamia shells (kg) & 1.9938 & & $6.07 \mathrm{E}-02$ \\
\hline Pongamia seedcake (kg) & 2.1445 & & $6.53 \mathrm{E}-02$ \\
\hline Crude Pongamia oil (L) & 1.0450 & & $3.18 \mathrm{E}-02$ \\
\hline Refined Pongamia oil (L) & 1.0137 & & $3.09 \mathrm{E}-02$ \\
\hline \multicolumn{4}{|l|}{ Hybrid Fuel Production } \\
\hline \multicolumn{4}{|l|}{ Input } \\
\hline Ethanol (L) & 0.2426 & & 7.38E-03 \\
\hline Butanol (L) & 0.2304 & & 7.01E-03 \\
\hline Electricity (kWh) & 0.0005 & & $1.59 \mathrm{E}-05$ \\
\hline Diesel (oil tanker round trip - hybrid fuel transport) $(\mathrm{km})$ & 0.0193 & & $5.89 \mathrm{E}-04$ \\
\hline \multicolumn{4}{|l|}{ Output } \\
\hline Pongamia - ethanol hybrid fuel (L) & 1.4433 & & 4.39E-02 \\
\hline
\end{tabular}

Table 5

$\mathrm{CO}_{2}$ emissions per MJ of energy from Pongamia - ethanol hybrid fuel.

\begin{tabular}{ll}
\hline Items & $\mathrm{g} \mathrm{CO} 2 \mathrm{eq} / \mathrm{MJ}$ \\
\hline Cultivation Phase & \\
Polybags production and discharge $(\mathrm{kg})$ & 0.0657 \\
Organic fertilizer $(\mathrm{kg})\left(\mathrm{N}_{2} \mathrm{O}\right)$ & 0.0182 \\
Diesel fuel - irrigation (L) & $5.84 \mathrm{E}-07$ \\
Glyphosate (L) & 0.2447 \\
Diesel fuel - transportation for cultivation phase $(\mathrm{km})$ & 1.9708 \\
Sub Total & 2.2994 \\
& \\
Pongamia Oil Extraction and Refining & \\
Electricity (kWh) & 1.1540 \\
Phosphoric acid (kg) & 0.0916 \\
Sodium hydroxide (kg) & 0.0466 \\
Sub Total & 1.2922 \\
& \\
Hybrid Fuel production & \\
Ethanol Production (L) & 1.1849 \\
Butanol Production (L) & 0.8068 \\
Electricity (kWh) & 0.0081 \\
Diesel fuel - hybrid fuel transportation $(\mathrm{km})$ & 0.4557 \\
Sub Total & 2.7392 \\
Total & 6.0470 \\
\hline
\end{tabular}

$3.40 \%$ and $5.84 \%$ less than unblended diesel, respectively. The $\mathrm{E}_{17} \mathrm{~B}_{16} \mathrm{DPO}_{67}$ blend shows better performance with reduced emissions and at maximum load, it shows $\mathrm{NO}$ emission of $345.2 \mathrm{ppm}, \mathrm{CO}$ emission of $293.8 \mathrm{ppm}, \mathrm{SO}_{2}$ emission of $6 \mathrm{ppm}$ and $\mathrm{CO}_{2}$ emission of $0.91 \mathrm{vol} \%$. In comparison with diesel, the $\mathrm{CO}_{2}$ emission from such blend is reduced by $11 \%$, NO emission is reduced by $14.24 \%$ and $\mathrm{SO}_{2}$ emission is reduced by $14.29 \%$. The environmental impact analysis for the life cycle production of Pongamia hybrid fuel shows emission of $6.05 \mathrm{~g} \mathrm{CO}_{2} \mathrm{eq} / \mathrm{MJ}$, which is significantly lower than that of petroleum diesel.

Therefore, the degummed Pongamia hybrid fuels are suitable alternatives for diesel to run diesel powered fishing boats, inter-island shipping vessels and smaller diesel power plants for household electricity without any engine modifications in remote and outer islands of developing countries, like the Pacific Island Countries.

\section{Credit author statement}

Salvin Sanjesh Prasad: Conceptualization, Methodology, Data curation, Formal analysis, Investigation, Validation, Software, Visualization, Roles/Writing - original draft; Writing - review \& editing. Anirudh Singh: Conceptualization, Methodology, Project administration, Resources, Software, Supervision, Validation, Roles/ Writing - original draft, Writing - review \& editing. Surendra Prasad: Methodology, Resources, Supervision.

\section{Funding}

This research did not receive any specific grant from funding agencies in the public, commercial, or not-for-profit sectors. The research was carried out using my Master of Science research budget from Department of Physics, for which I had paid tuition fees.

\section{Declaration of competing interest}

The authors declare that they have no known competing 
financial interests or personal relationships that could have appeared to influence the work reported in this paper.

\section{Acknowledgement}

This research did not receive any specific grant from funding agencies in the public, commercial, or not-for-profit sectors. The authors would like to sincerely thank Dr. David Rohindra from the University of the South Pacific for providing the technical support.

\section{References}

[1] M. Siwek, A.G. Chmielewski, Process Engineering Aspects of Diesel Engine off Gases Treatment, Institute of Nuclear Chemistry and Technology, 2018.

[2] P.J. Singh, J. Khurma, A. Singh, Preparation, characterisation, engine performance and emission characteristics of coconut oil based hybrid fuels, Renew. Energy 35 (9) (2010) 2065-2070.

[3] I. Adam, A. Abdul Aziz, M. Heikal, S. Yusup, A. Ahmad, E. Zainal Abidin, Performance and emission analysis of rubber seed, palm, and their combined blend in a multi-cylinder diesel engine, Energies 11 (6) (2018) 1522.

[4] M.M. Rahman, S.B. Mostafiz, J.V. Paatero, R. Lahdelma, Extension of energy crops on surplus agricultural lands: a potentially viable option in developing countries while fossil fuel reserves are diminishing, Renew. Sustain. Energy Rev. 29 (2014) 108-119.

[5] K. Kaygusuz, Energy for sustainable development: a case of developing countries, Renew. Sustain. Energy Rev. 16 (2) (2012) 1116-1126.

[6] A. Singh, Biofuels and Fiji's roadmap to energy self-sufficiency, Biofuels 3 (3) (2012) 269-284.

[7] R.K. Pandey, A. Rehman, R. Sarviya, Impact of alternative fuel properties on fuel spray behavior and atomization, Renew. Sustain. Energy Rev. 16 (3) (2012) 1762-1778.

[8] N.D. Rao, B.S. Premkumar, M. Yohan, Study of different methods of using vegetable oil as a fuel for compression ignition engine, Glob. J. Res. Eng. 12 (4A) (2012).

[9] Z. Franco, Q. Nguyen, Flow properties of vegetable oil-diesel fuel blends, Fuel 90 (2) (2011) 838-843.

[10] Department of Energy, Energy efficiency and renewable energy, U.S. Straight vegetable oil as a diesel fuel? in: A D (Ed.), Bioenergy Elsevier Inc., 2015 pp. 189-192.

[11] I.T. Nazal, H.H. Al-Kayiem, Experimental characterization of diesel engine performance fuelled by various sunflower oil-diesel mixtures, J. Appl. Sci. 12 (24) (2012) 2604-2609.

[12] S. Narayan, S. Sharma, Plant Oils (Dewaxed \& Degummed) as a Fuel for Diesel Engine, 2018.

[13] S.C. Mat, M. Idroas, M. Hamid, Z. Zainal, Performance and emissions of straight vegetable oils and its blends as a fuel in diesel engine: a review, Renew. Sustain. Energy Rev. 82 (2018) 808-823.

[14] B. Balakrishna, Vegetable oil as fuel in CI engine: problems and possible solutions, Int. J. Eng. Sci. Technol. 4 (11) (2012) 4687-4690.

[15] F.F. Banihani, Transesterification and production of biodiesel from waste cooking oil: effect of operation variables on fuel properties, Am. J. Chem. Eng. 4 (6) (2017) 154

[16] D.Y. Leung, X. Wu, M. Leung, A review on biodiesel production using catalyzed transesterification, Appl. Energy 87 (4) (2010) 1083-1095.

[17] A. Rodrigues, J.C. Bordado, RGd Santos, Upgrading the glycerol from biodiesel production as a source of energy carriers and chemicals - a technological review for three chemical pathways, Energies 10 (11) (2017) 1817.

[18] C. Attaphong, Formulations and Characteristics of Vegetable Oil-Based Microemulsion Biofuels. School of Civil Engineering And Environmental Science. Doctor of Philosophy, University of Oklahoma, 2014, p. 149.

[19] K.N. Gopal, R.T. Karupparaj, Effect of pongamia biodiesel on emission and combustion characteristics of DI compression ignition engine, Ain Shams Eng. J. 6 (1) (2015) 297-305.

[20] A. Lelin, N. Azhagesan, C. Rex, K. Thyagarajan, Performance of diesel engine operating with pongamia methyl esters as biodiesel, Asian J. Sci. Res. 5 (3) (2012) 153-161.

[21] S.K. Karmee, A. Chadha, Preparation of biodiesel from crude oil of Pongamia pinnata, Bioresour. Technol. 96 (13) (2005) 1425-1429.

[22] A.K. Vuppaladadiyam, J. Sangeetha, V. Sowmya, Transesterification of pongamia pinnata oil using base catalysts: a laboratory scale study, Univ. J. Environ.
Res. Technol. 3 (1) (2013).

[23] M.V.R. Prasad, Vayugrid-Value Chain Manager Around Bioenergy and Biofuels, Vayugrid, 2012.

[24] A. Atabani, A. Silitonga, H. Ong, T. Mahlia, H. Masjuki, I.A. Badruddin, et al., Non-edible vegetable oils: a critical evaluation of oil extraction, fatty acid compositions, biodiesel production, characteristics, engine performance and emissions production, Renew. Sustain. Energy Rev. 18 (2013) 211-245.

[25] N. Rao, B.S. Premkumar, M. Yohan, Performance and emission characteristics of straight vegetable oil-ethanol emulsion in a compression ignition engine, ARPN J. Eng. Appl. Sci. 7 (4) (2012) 447-452.

[26] N. Arpornpong, C. Attaphong, A. Charoensaeng, D.A. Sabatini, S. Khaodhiar, Ethanol-in-palm oil/diesel microemulsion-based biofuel: phase behavior, viscosity, and droplet size, Fuel 132 (2014) 101-106.

[27] B.B. Breaux, The Effect of Elevated Water Content on Ethanol Combustion. The Department Of Mechanical Engineering. Master of Science. B.S. Louisiana State University, Louisiana State University, Baton Rouge, Louisiana, 2012, p. 122.

[28] V. Sethi, S.K. Mehta, A.K. Ganguli, S. Vaidya, Understanding the role of cosurfactants in microemulsions on the growth of copper oxalate using SAXS, Phys. Chem. Chem. Phys. 21 (1) (2018) 336-348.

[29] C. Laili, S. Hamdan, Phase diagrams of W/O microemulsion stabilised by nonionic surfactants to be used as templates for microemulsion polymerisation, Orient. J. Chem. 31 (3) (2015) 1595-1599.

[30] A. Charoensaeng, S. Khaodhiar, D.A. Sabatini, N. Arpornpong, Exhaust emissions of a diesel engine using ethanol-in-palm oil/diesel microemulsion-based biofuels, Environ. Eng. Res. 23 (3) (2018) 242-249.

[31] M.H. Salmani, S. Rehman, K. Zaidi, A.K. Hasan, Study of ignition characteristics of microemulsion of coconut oil under off diesel engine conditions, Eng. Sci. Technol. Int. J. 18 (3) (2015) 318-324.

[32] O. Zufarov, S. Schmidt, S. Sekretár, Degumming of rapeseed and sunflower oils, Acta Chim. Slovaca 1 (1) (2008) 321-328.

[33] Schwab AW, Pryde EH. Microemulsions from vegetable oil and aqueous alcohol with 1-butanol surfactant as alternative fuel for diesel engines. Google Patents; $1985: 1-8$

[34] Y. Yuan, S-m Li, F-k Mo, D-f Zhong, Investigation of microemulsion system for transdermal delivery of meloxicam, Int. J. Pharm. 321 (1) (2006) 117-123.

[35] B. Esteban, J.-R. Riba, G. Baquero, A. Rius, R. Puig, Temperature dependence of density and viscosity of vegetable oils, Biomass Bioenergy 42 (2012) 164-171.

[36] M.Y. Selim, Reducing the viscosity of Jojoba Methyl Ester diesel fuel and effects on diesel engine performance and roughness, Energy Convers. Manag. 50 (7) (2009) 1781-1788.

[37] R.C. Flagan, J.H. Seinfeld, Fundamentals of Air Pollution Engineering, Courier Corporation, 2012.

[38] G.S. Hebbar, NOx from diesel engine emission and control strategies - a review, Int. J. Mech. Eng. Robot. Res. 3 (4) (2014) 471.

[39] A.T. Russell, Combustion emissions, Air Pollut. Canc. 37 (2013).

[40] L.S. Jaffe, Ambient carbon monoxide and its fate in the atmosphere, J. Air Pollut. Control Assoc. 18 (8) (1968) 534-540.

[41] J. Sheehan, V. Camobreco, J. Duffield, H. Shapouri, M. Graboski, K. Tyson, An Overview of Biodiesel and Petroleum Diesel Life Cycles, National Renewable Energy Lab., Golden, CO (US), 2000.

[42] L.A. Chandrashekar, N. Mahesh, B. Gowda, W. Hall, Life cycle assessment of biodiesel production from pongamia oil in rural Karnataka, Agric. Eng. Int: CIGR J. 14 (3) (2012) 67-77.

[43] IPCC-GNGGI, N2O emissions from managed soils, and CO2 emissions from lime and urea applications, in: IPCC Guidelines for National Greenhouse Gas Inventories, vol. 4, 2006, pp. 1-54. USA; 2006.

[44] U.N. FAO, Global Database of GHG Emissions Related to Feed Crops. Version 1. Rome, Food and Agriculture Organization of the United Nations and Livestock Environmental Assessment and Performance Partnership, 2015, pp. 1-30.

[45] T. Silalertruksa, J. Kawasaki, Guideline for Greenhouse Gas Emissions Calculation of Bioenergy Feedstock Production and Land Use Change (LUC): A Case Study of Khon Kaen Province, Thailand, 2015.

[46] Z. Samaras, K. Zierock, Emissions Inventory Guidebook - Road Transport, 1999, pp. $1-100$.

[47] R.I.S.O. UNEP, Emissions Reductio Profile - Fiji. Denmark, 2013, pp. 1-25.

[48] JRC Science for Policy Report, Definition of Input Data to Assess GHG Default Emissions from Biofuels in EU Legislation, Version 1 c, Luxembourg, 2017, pp. $1-314$.

[49] S. Väisänen, J. Havukainen, V. Uusitalo, M. Havukainen, R. Soukka, M. Luoranen, Carbon footprint of biobutanol by ABE fermentation from corn and sugarcane, Renew. Energy 89 (2016) 401-410.

[50] M. Eriksson, S. Ahlgren, LCAs of Petrol and Diesel, 2013. 